\title{
FACTORS AFFECTING FLOOD MANAGEMENT IN BIHAR, INDIA
}

\author{
Sangeeta Choudhary \\ Techno India NJR Institute of Technology \\ Udaipur, Rajasthan
}

\section{Research Article}

Received: 25.05.2020

Accepted: 31.05.2020

Published: 15.06.2020

\section{ABSTRACT}

\begin{abstract}
Bihar is facing a flood problem every year. This paper includes all the major factors which increase flood level in Bihar such as heavy rainfall, a large number of rivers, topography of the area, sand mining, and silt accumulation. There are some factors which are directly responsible and others are indirectly responsible for flood hazard. Heavy rainfall and a large number of rivers are directly responsible factors. The capacity of rivers and reservoirs is reduced due to silt accumulation and deforestation upstream in Nepal is the reason behind silt accumulation in rivers and reservoirs through heavy rainfall. Watershed management is not very successful because most of the plain area. The hydrology of Bihar is also disturbed due to excess sand mining. The built-up area of the state is increasing and this is resulting in heavy surface runoff, because there is no open area to hold the water. The increased flow also washes the fertile soil of the agricultural area of Bihar.
\end{abstract}

Keywords: Flood, Silt accumulation, Sand mining, Deforestation, Rainfall.

\section{INTRODUCTION}

Flood is the main problem in Bihar which affects the development of the state. Bihar is surrounded by three states of India and one country Nepal. West Bengal is situated east of Bihar while Uttar Pradesh in the west and Jharkhand in the south. Nepal is a neighboring country in the north of Bihar. The area of Bihar is around 94,163 square kms and it is placed between $24^{\circ} 20^{\prime} \mathrm{N}$ to $27^{\circ} 31^{\prime} \mathrm{N}$ latitude and $83^{\circ} 20^{\prime} \mathrm{E}$ to $88^{\circ} 18^{\prime} \mathrm{E}$ longitude. It is a completely land-locked state as shown in figure 1 . Its average elevation above sea level is 173 feet. Many factors are responsible for the failures of water management in Bihar. Floods are causing the loss of lives and public property. There is also a bigger economic impact, as they disrupt economic activities, thus affecting growth.
Bihar is considered a very backward state. Flood affects agriculture as well as industrial activities in this state. There is a requirement of execution of proper water management for preventing the damage. Many construction projects are delayed due to the flood problem. Flood also affects existing structures, flora, fauna, etc. Bihar has many natural minerals which can make it a very rich and developed state with many employment opportunities. Existing situations are not in favorable condition so poverty, unemployment, and slow development rate are very big problems in Bihar. Flood plays the main role in decreasing growth in transportation, health, education, agriculture, and the construction sector. It is difficult to solve the flood problem in Bihar because many factors depend on each other. Silt accumulation

*Corresponding author: Sangeeta27apr@gmail.com 
fails the embankment's design but silt accumulation in rivers and reservoirs occurs due to deforestation.

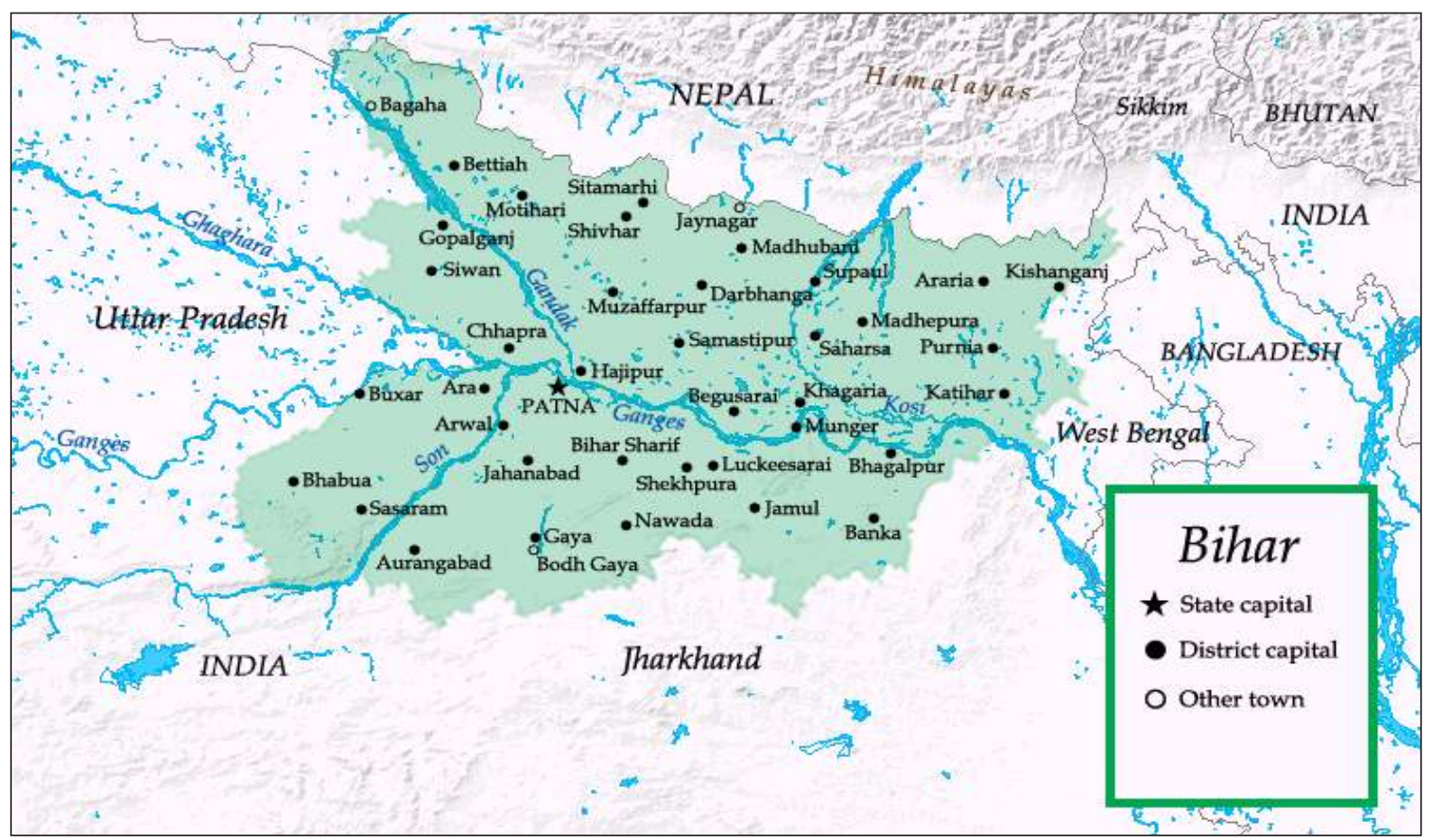

Figure 1: Map of Bihar (1)

It is important to identify the reasons behind flood hazards to adopt correct remedies against them. It is required to implement the National Water Policy and make National Silt Management Policy to control flood problems. National Water Policy was revised in 2012. Water is a natural resource that is necessary for economic growth so the major prominence of this policy to treat water as an economic good which the ministry claims to encourage its conservation and efficient use. All factors are included in this paper which affects the flood management in Bihar.

\section{Factors affect flood management}

- Heavy Rainfall

- Web of Rivers

- Deforestation in Nepal
- Silt accumulation in rivers and reservoirs

- Illegal sand mining from rivers

- Blockage of distributaries paths due to the built-up area

- Unable to do Watershed Management

- Failure of existing embankments

- Dependency on Nepal

Heavy Rainfall: Uneven distribution throughout the year of rainfall is the most important factor in creating a flood. It is observed that the annual mean rainfall of Bihar is $122.4 \mathrm{~cm}$. Its $84 \%$ rainfall occurs during monsoon, $7 \%$ in premonsoon, $6 \%$ in post-monsoon and $3 \%$ in winter season (2) (3) as mentioned in figure 2. 


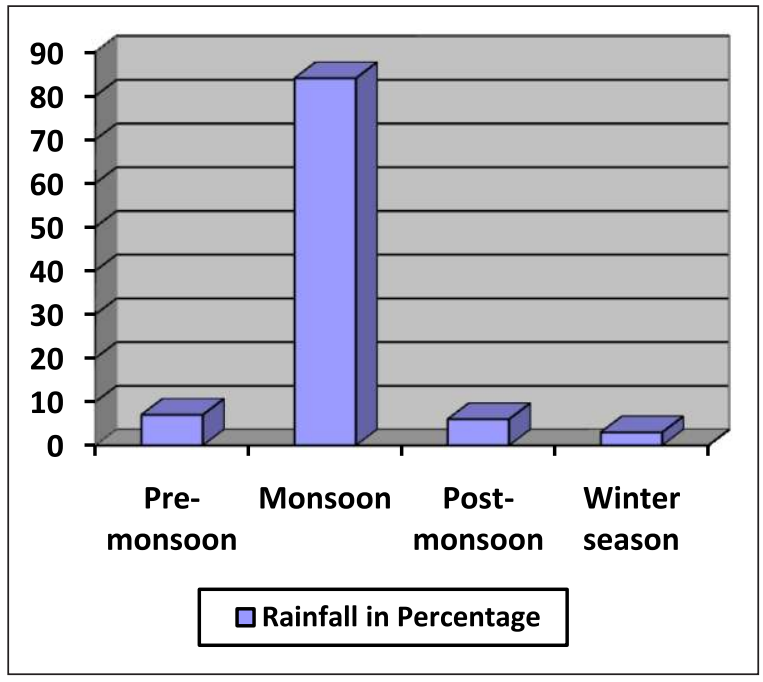

Figure 2: Graph represents the uneven distribution of rainfall throughout the year

Web of Rivers: Many rivers such as Ganga, Kosi, Ghaghara, Punpun, Gandak, Phalgu, Karmanasa, etc flow in the crisscross manner in Bihar as shown in figure 1. The Bihar plain is divided by the Ganga river which flows the Ganga river has many tributaries and Kosi is one of the major tributaries and it comes from Nepal. There are seven tributaries in Nepal that meet in the Kosi river in the north of the India-Nepal border as shown in figure 3 which is known as seven rivers. Kosi river covers a very large area in Bihar and it increases the flood disaster during the rainy season. Figure 4 is a Google map of the Kosi river in Bihar.

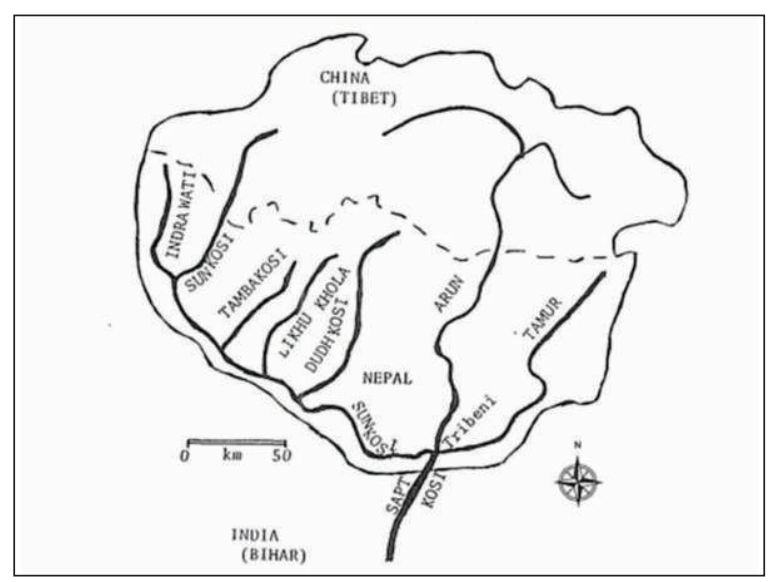

Figure 3: Tributaries of the Kosi river in Nepal

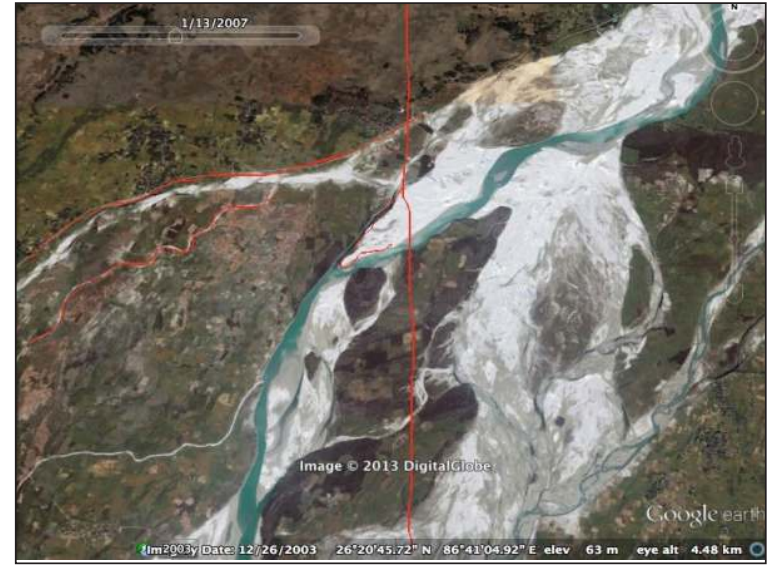

Figure 4: Kosi river in Bihar.

Deforestation in Nepal: Nepal is situated upstream of Bihar. Translation of forest to agricultural and other expansion in the central hills of Nepal, which drastically increased to the flood damage in north Bihar and disturb the environmental equilibrium. Deforestation is also responsible for sand and silt erosion and accumulation. This accumulation of silt occurs in rivers and reservoirs in Bihar. Central and state governments can not decide on the policies of Nepal. Collaborative programs between India and Nepal can reduce this problem.

Silt Accumulation: Silt accumulation is also a major problem as it reduces the capacity of rivers and reservoirs which invites flood hazard. There is the requirement of a national policy on silt management and it will make the situation easy to execute projects on silt management. Excessive deposit of silt occurs in the Ganga river. Kosi river joins the Ganga river near Kursela and its waters hold a heavy silt load and the river has a steep gradient. A better sediment removal technology is required because that accumulation is growing every year. Deforestation in Nepal is also a reason for increasing silt quantity in rivers in Bihar.

Illegal sand mining from rivers: Illegal sand mining in a haphazard manner is disturbing the hydrology of rivers in Bihar. Riverbanks and adjacent lands are damaged as shown in figure 5 due to sand mining and river changes in the path of the natural flow. It becomes the reason for a flood in that area. 


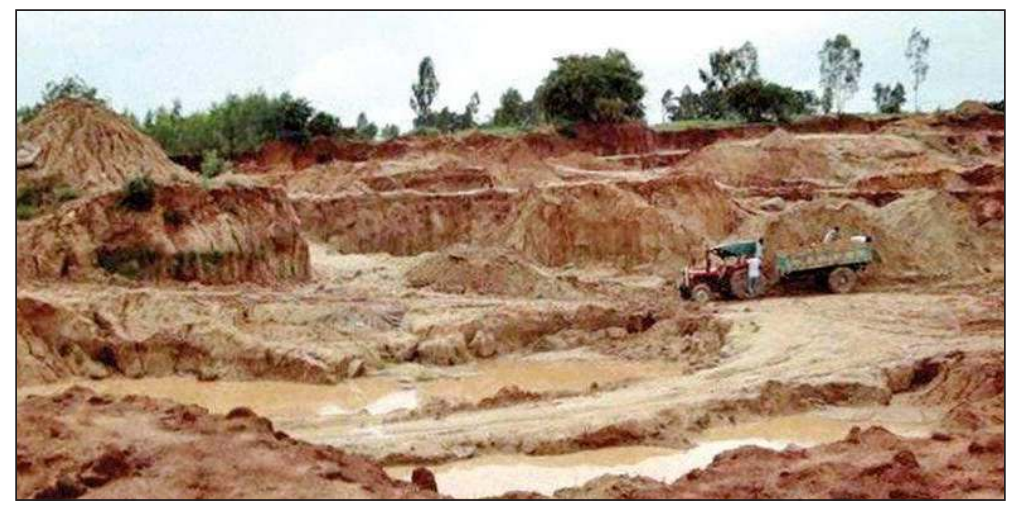

Figure 5: Erosion of River Bank due to sand mining (7)

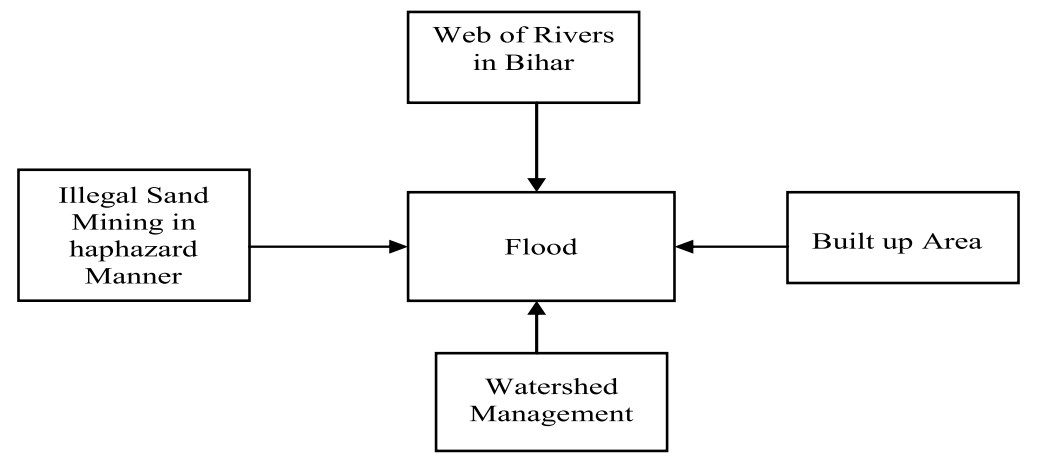

Figure 6: Independent Factors of Flood Hazard in Bihar.

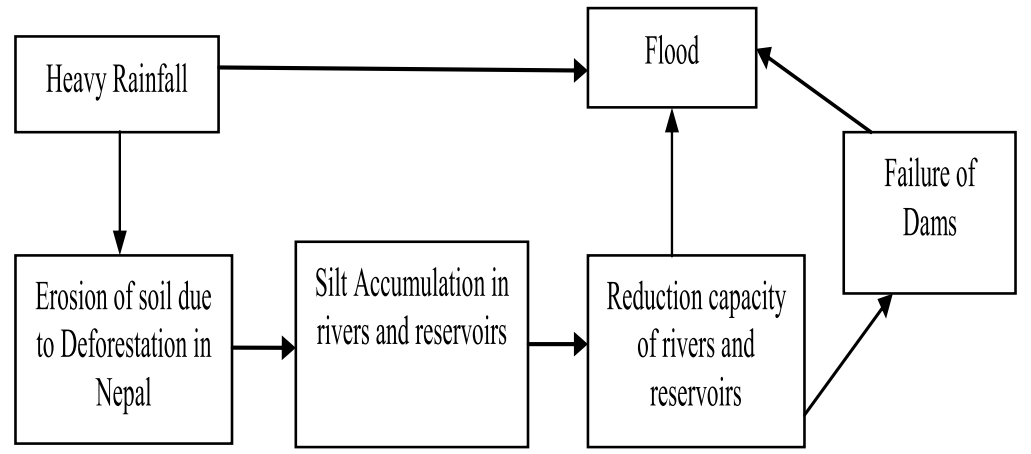

Figure 7: Dependent Factors of Flood Hazard in Bihar.

Dependency on Nepal: Nepal is situated upstream in the north of Bihar. Pre-monsoon preparation is required on the Nepal side to prevent the flood impact in Bihar. Nepal has obstructed the Bihar government from flood prevention-related work by putting barriers and not allowing the movement of people from across the Indian border in 2020. There is a lack of successfully implemented collaborative programs between Nepal and Bihar government. The dependency of Bihar on Nepal is high for flood management due to the geographical location of both. Bihar is placed downstream in the south of Nepal. Soil deposition happens in rivers in Bihar due to deforestation in Nepal. 


\section{RESULTAND DISCUSSION}

Above mentioned factors are responsible for flood disaster in Bihar. Some factors depend on other factors and some are independent factors. Figures 6 and 7 represent the interrelationship between factors affecting flood. Deforestation in Nepal is disturbing the environmental equilibrium of Nepal as well as Bihar. The major part of the accumulated silt in rivers is present due to deforestation and heavy rainfall. Silt accumulation has reduced the capacity of rivers and reservoirs and ultimately it becomes the reason for dam failure and flood hazard.

\section{CONCLUSION}

Bihar is a highly flood affected area in India. There are many reasons which are responsible for flood disaster every year. Heavy rainfall in monsoon time is a direct reason whereas deforestation, silt accumulation in rivers, reduction capacity of reservoirs and rivers, and deforestation are indirect and dependent reasons of flood hazard. There are some more reasons such as sand mining from rivers in a haphazard manner, more number of rivers in a crisscross pattern, Blockage of distributaries paths due to built-up area and less failure of watershed management. A national silt management policy is required for scientifically removing silt without disturbing the hydrology of the rivers. Embankment failure and reduction capacity of rivers and reservoirs will be solved through successful silt removing activity

\section{BIBLIOGRAPHY}

1. Zakuragi. wikimedia.org. wikimedia.org website. [Online] June 29, 2008. https://commons.wikimedia.org/wiki/File:B iharimap.png.

2. Observed Rainfall Variability and Changes over Bihar State. Guhathakurta, Pulak \& Kumar, Sudeep \& Menon, Preetha \& Prasad,
Ashwini \& Sangwan, Neha \& Advani, S. E S S O / I M D / H S / R a i n f a l l Variability/04(2020)/ 28, Pune : s.n., January 2020, Climate Research And Services India Meteorological Department Ministry Of Earth Sciences Pune.

3. Long term Trend in Rainfall over Bihar during the Period 1871-2011. S.I. Laskar, Naresh Kumar, Sanjay Bist. 2014, New Delhi : Indian Meteorological Society, 2014, vayumandal.

4. Inland delta building activity of Kosi river. Gole, C. V., and Chitale, S. V. 1966, Journal of the Hydraulics Division, American Society of Civil Engineers, Vol. 92, pp. 111-126.

5. Hydrologic Regime of The Sapt Kosi. Kattelmann, Richard. S.l. : IAHS, August 1991, Hydrology for the Water Management of Large River Basins, Vol. 201, pp. 139-147.

6. Saunders, Ryan. Kosi River. ICE Case Studies. s.l., Bihar, India : http://mandalaprojects.com/ ice/icecases/kosi-river.htm, December 2013.

7. TNN. Times of India. Times of India Website. [Online] Oct 4, 2019. https://timesofindia. indiatimes.com/city/bhopal/govt-to-allotsand-mining-lease-for-3-years-tenderprocess-to-open-today/articleshow/ 71430913.cms.

8. Upadhya, Kumar. Successes and Failures In Watershed Management In The Asia-pacific Region (1982 TO 2002). [ed.] Larry Tennyson, Kumar Upadhyay and Roger White Moujahed Achouri. Proceeding of the Asian Regional Workshop on Watershed Management. September 11-13, 2003, pp. 43-52.

9. Annual Flood Damage Report. Disaster Management Department. Patna, Bihar : http://disastermgmt.bih.nic.in/, 2015. Periodic Report. 